\title{
Learning Spaces for University Administrators - How and to what Extent they are Recognized
}

\section{Daiva Bukantaite}

The article describes learning places at workplaces identified and recognised by the university administrators. In the process of the qualitative research, during the participatory photo interview, workplaces and spaces of processes and human learning were identified that were expanded by the individuality, emotional accent, routine, fact, "hot event", peer assistance, social partner initiatives and alumni input subcategories. University administrators see learning in the workplace not as an indispensable activity when striving to accomplish a given task, but as a component of the task performance process.

Keywords: learning spaces, university administrators, participatory photo interview

\section{Introduction}

Many universities most often position themselves as exceptionally active, innovative, modern, research based organisations ensuring opportunities for the expression of personal freedom and initiative. These universities declare that they educate students that are brave, creative and open-minded, are not afraid to experiment and think critically. However, these organisations constantly face different challenges: increasing local and international competition, growing society expectations, financial pressure, higher education becoming a mass phenomenon, consumerist approach to the university (Vettori, Lueger, Knassmüller, 2007). Another exceptional challenge is the unavoidable internationalisation of the university activities, such as exchange of students and teachers, creation of international programmes and projects and establishment of the university subsidiaries or departments in other countries. Thus universities become not only the creators of knowledge but also service providers.

As Cardoso, Carvalho, Santiago (2011) observe, at present science has turned into a certain business that already cannot be effectively implemented into the frame 
of a traditional university model. Orientation to the needs of society and specific people becomes one of the overall concepts of the new university. The most significant aspect of this idea is to acknowledge that the existence of the careless academic society is over, and the university has to refocus from "process" to "result", from teaching to learning, from traditional studying to learning based on information technologies or even open learning.

One of the most important developers of this process are university administrators who have no other choice but to react to changes "here and now", have to become manifold and have to be able to perform different activities. Thus the administrator becomes not only the executor of university undertakings, but also a learner in a specific activity. Still, in order to accomplish this new role, the assurance of the systematic development of the administrative processes is not sufficient; it is necessary to master new competencies and expand the scope of own learning opportunities.

The aim of the research: to identify the learning spaces of university administrators in their workplace.

Research questions:

- To what extent is the learning of university administrators in the workplace comprehended?

- What factors encourage university administrators to learn in their workplace?

\section{Research methodology}

The context of research. The research was conducted at the 8 universities in Lithuania. These universities represent by itself the classical universities with the number of students ranging from 6400 to 12000 , providing the bachelor, master and doctoral degree studies in the fields from social sciences too biologic.

The choice of the research method. Participatory photo interview was chosen as a research method. Kolb (2012) and Edwards (2011) state that photographs are used to evoke a stronger impression as points of intercultural social intersections, sources of analysis, as a research object, visual and sensory systems. Larson (1988: 68)) calls 
photography an image used as a mediator enabling the understanding of the research participants' attitude towards reality.

The research was based on the Social theory (Kilduff/Mehra, 1997) maintaining that knowledge is based on individual interpretation which in turn relies on the socially determined classification of reality. Knowledge is created by society and an individual. Valuable knowledge is not necessarily recorded, but it becomes a public agreement and is changing in the social context.

Data collection. The data was collected in several stages: firstly, the research participants were contacted, research questions were presented and they were asked to photograph their learning spaces at work; later during the interview the photographs were analysed and grouped according to the categories distinguished by the research participant. Participants answered the researcher's questions and reflected on their experience. In the process, the requirements of the participatory photography method presented by Kolb (2012) were followed.

Data analysis method. A qualitative content analysis method was selected (Mayring, 2000), allowing the analysis of the research data considering their compliance with the research questions, the experience of the research participants, as well as their opinion and feelings, sociocultural basis and the research environment. Qualitative content analysis allows the opportunity to discover obvious or hidden meanings, themes and models, instead of word counting and objective content selection (Zhang, Wildemuth, 2009).

Research sample. The administrators of 8 universities (two men and six women) participated in the research. Those under research were selected with the help of the convenience sampling criterion. The main requirement of the research participants' selection was the administration of international activity (work in the international department or with international students, organisation of teacher and student exchange, administration of international programmes). When describing the research results, research participants were coded by symbols P1-P8.

The research instrument was comprised of three interview questions:

- Tell why you chose this for making a photo. How are these photographs connected?

- How does the content of your photograph encourage you to learn?

- What competencies do you develop in the photographed situation? 
Research ethics. All research participants benevolently took part in the research. Principles of confidentiality, personal dignity, information intelligibility, benevolence and ethics were ensured.

Research limitations were determined by the research participants' fears to be recognised.

In the article, university administrators are the persons performing administrative activities in the university; these are the employees of the Rector's and Dean's offices, as well as of different administrative divisions whose duties do not include teaching students.

\section{The medium of knowledge created in the university}

The challenges that modern universities face are numerous - to help orientate in the multitude of alternative approaches, theories and truths, to offer new knowledge systems and structures, to enable the person to live purposefully and comfortably enough in the super-competence mental environment, where there is a lot of confusion, mess and opportunities (Barnett R. 2000).

Universities also exist in order to maintain and create themes, ideas and things that can be out of fashion and unpopular, but would foster understanding that they are important (Jokubaitis, 2013). In $2009 \mathrm{~F}$. Webster observed that a university is an oxymoronic institution, a set of different features, lacking a unifying idea - even academic communities cannot identify what their universities represent as they have lost the feelings of entirety.

A university is a corporative institution of researchers each member of which is immersed in a specific field of science; therefore, individualisation and intellectual autonomy are characteristic of the academic community members (Salamavičius, 2010).

According to Jucevičienè, Edintaite (2014), a university as an institution of research and studies creates scientific knowledge and transmits it to the society, transfers the cultural heritage, adds to the progress of society, concentrates cognitive powers of individuals and promotes the changes of knowledge, meanings, abilities and competencies. It is significant that competitive advantage is increasingly acquired by those organisations which are able to employ all the knowledge of the organisation, collective and individual, explicit, implicit and tacit knowledge that earlier did not seem of value for the organisation or was not known.

Universities are knowledge creating organisations. Knowledge organisations have the main wealth - unique knowledge that is hard to copy, that has substantial 
significance to the value of the organisation and the creation of products and services. This wealth, according to Misiūnaitè- Bačiauskienè, Jucevičienè. (2014) is the individual and collective knowledge and abilities of the organisation employees creating the competence nucleus of a knowledge organisation. The authors maintain that hereby a university faces a challenge to create and implement such knowledge management models and means that would stimulate, maintain and speed up organisational learning. Thus, if a university is a knowledge-creating organisation, it becomes, by itself, a learning place for all inside it. Consequently, organisational knowledge that is acknowledged as valuable becomes a learning result. In addition, it is noted that organisational knowledge reflects a functional approach to knowledge emphasising what knowledge is necessary to achieve the given organisational goals or to perform a certain activity. In the meantime, organisational knowledge covers all the knowledge of all the surrounding individuals, of all groups in the organisation and all knowledge of the organisation level - explicit, implicit (known, but not articulated yet) and tacit (Jucevičienè 2007).

In 1992, Argyris observed that organisations themselves do not learn; it is the employees who learn and act so that learning processes take place in organisations the process of organisational learning is initiated. The organisation has to create favourable conditions for this activity. Organisational learning takes place at three levels: individual, group and of all academic community. Learning of an individual at the individual level is related with his specific activity carried out in the organisation. At this point, the knowledge conversion theory by Nonaka and Takeuchi (1995) has to be referred to - it speaks of the knowledge creation process as a continuous and interactive activity during which the tacit knowledge (unknown to the organisation) is converted to the explicit, knowledge is accumulated and its amount increased. Still, it is exceptionally important to avoid learning imitation.

In this article, knowledge is categorised as explicit, implicit and tacit. According to Awad and Ghaziri (2004) tacit knowledge is demonstrated in the activity, it is hard to articulate and it is acquired through experience. Implicit knowledge is perceived by the individual; he knows its structure but has not expressed it orally or in writing. It is enough to want and implicit knowledge is articulated, while the expression of tacit knowledge requires much effort, it cannot be even be expressed, according to Polanyi (1958), as it is hidden in activity and cannot be separated from it (Jucevičienè , Mozuriūnienė 2009). The mentioned authors say that organisational knowledge is comprised not only of the explicit organisational knowledge but also of the knowledge of individuals, their groups and the knowledge and knowing of all the organisational level that are characterised by the fact that all this knowledge and knowing are acknowledged in the organisation as creating value. Therefore, the organisation creates conditions for organisational learning enabling the formation of this organisational knowing. 
The university being a place of learning in essence, where intellectual emancipation (liberation from stereotypes and from submission to authorities, thinking when in the process of discussion an appropriate argument is acknowledged as the most important one) is enabled through thinking and knowledge transformation processes naturally becomes the place of organisational learning. Learning processes are self-serving and generating new knowledge (MisiūnaitèBačiauskienè., Jucevičienè 2014).

Organisational learning is considered an essential condition for organisation design, development and improvement. According to the mentioned authors, organisational learning is in essence a multi-voiced, constantly renewing, transformed and transforming knowledge creation process.

\section{The spaces of learning for university administrators}

Three categories disclosing the main learning spaces recognised by university administrators were chosen to present the results, namely: a workplace, processes and people.

\section{The 1st category. The workplace}

A subcategory: Individuality. A workplace was mentioned by all the participants of the research. Often it is unregulated space that an employee can create independently (see Figure 1.).

"My office desk often looks like it was after an explosion, complete chaosa lot of documents and stickers. When the administrator asks, I sometime I put things in order. For me it is important that it is the space where the creative process is happening, it is not only about the documents, but also about the new ideas, I solve everyday problems and emerging situations at my desk. (P8)".

A desk is also related with technologies used at work - a computer, a telephone, the Internet. The Internet is the unlimited learning space not only at work. The Internet is first of all searched for the necessary information, it also provides leisure opportunities. 
"The Internet is the place for me where I am every day, I search for the necessary information, I read news portals, different article; I don't have a profile in any social website. My colleagues often listen to music in the Internet, but it doesn't help me at work. I can record learning when I am searching for something specific, for example for the meaning of the word or a sample of a document that I need to prepare (P6)".

A desk is treated as a symbolic place for building relationship:

"I photographed two cups. I share a desk with my colleague with whom I not only drink coffee; we also solve all the problems. Everything is discussed, we share everything. This ever-day communication is undoubtedly the space for learning as well (P1)" (see Figure 1)

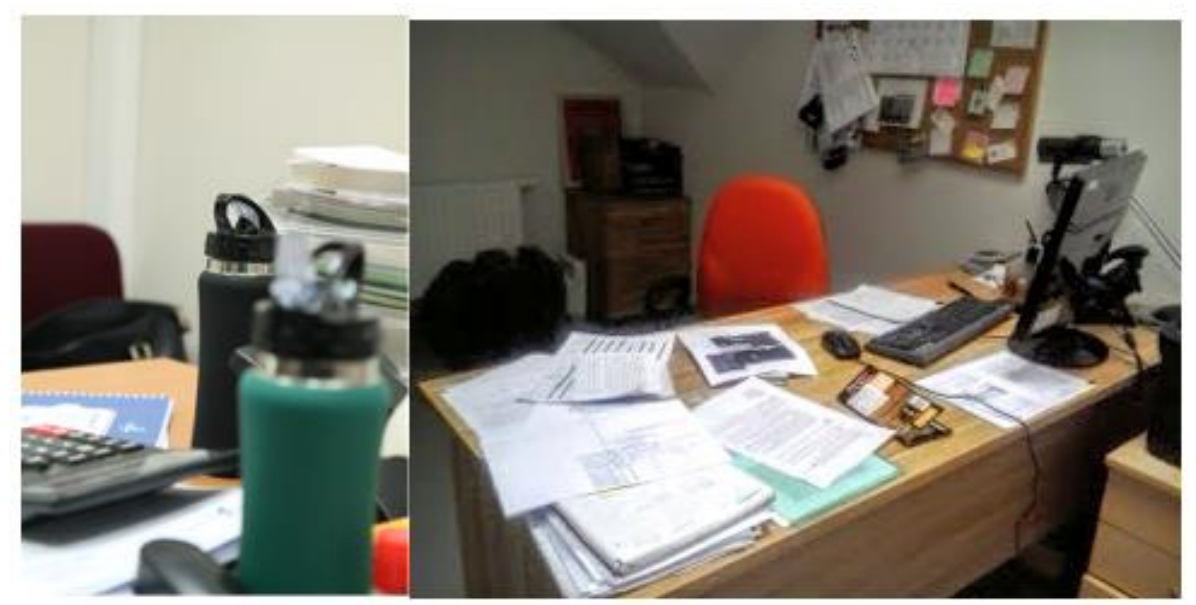

Figure 1: The office desk

Subcategory: Emotional highlights as a learning category were distinguished by research participants in a form of symbols (photos, souvenirs, lucky charms, etc.). On the one hand, a symbol probably could not be taken for learning space, but still it is very important for the learner as a component of that space. Symbols are related to identity and something personal, significant only to the specific person or a group of persons. It is interesting that all photographed symbols were connected only with the job (see Figure 2) 
"This little angel has travelled to all my work places. It reminds me of where I come from. It is a small gift from my first work place where I started as a student and every day I was learning from my colleague, where I felt good. I don't want to forget that and I wish that the mood of the time would follow me everywhere (P1). One administrator - the research participant photographed her child's picture. "When looking at my daughter's picture I draw inspiration and I smile. How much is that connected with my learning at work? After all, I am working not only for myself, but for her, as well. She inspires me for my further activity and work (P3)".

"Atmosphere", "mood", "a sense of community", "team spirit" are often indicated by some of the research participants as incentives for learning in the work place. They maintain that it is the most important factor determining their aspirations for development and creation of a higher education institution that would be pleasant to be and work in. "If you do your job and a little more than you were asked to, you always receive acknowledgement. That acknowledgement motivates me for further activity and learning (P4)"

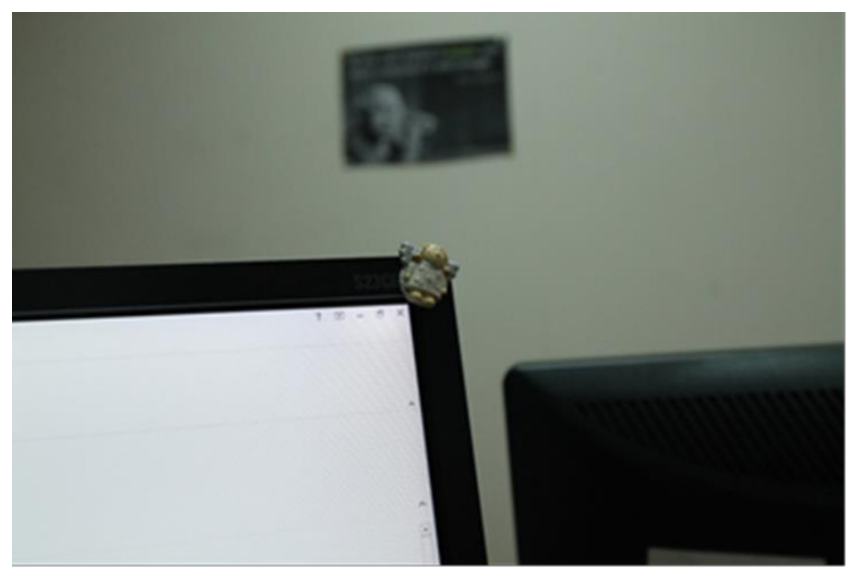

Figure 2: A lucky charm in the workplace 


\section{The 2nd category. Processes.}

Subcategory: Routine. The everyday activity processes that are more dynamic and therefore harder to photograph were mentioned by the majority of the research participants.

"Daily activity, creation of something new, one job after another - this is the main object of my learning in the work place. They are numerous and it is hard to single one out. I made a photo of an event plan and the identification card. Activities are intertwined. You would not be able to organise an event alone, you communicate, plan, run around. Often no one cares how much time you devoted for it, it is the final result that matters and in our case it has to be perfect. (P6)" (see Figure 3).

Processes are not only daily routine activities, but also strategies, formation of future activities that takes place constantly.

"Strategy creation is my invisible place for learning at work. We have a file where we record everything that is necessary to implement, what is important for us and our future. When we generated ideas and we did not record them, we used to lose them, therefore was a place found for their accumulation. Work with ideas is my favourite activity. (P5)".

The creation of strategy is distinguished by creative activity related to daily processes. 


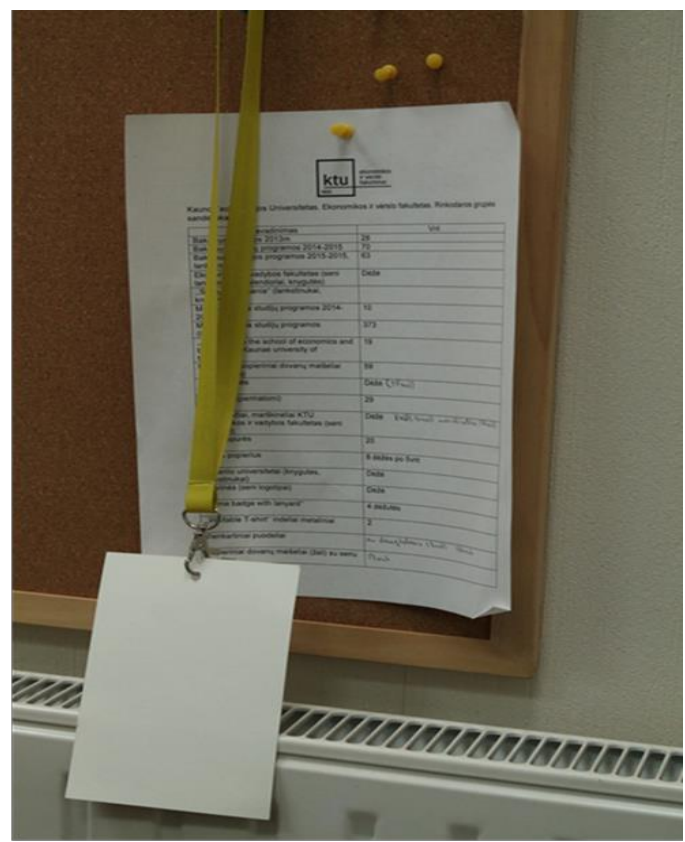

Figure 3: The plan of a future event

Subcategory: Facts an individual category of learning in the work place signify different past activities (events, projects, sessions, meetings). Some of them are remembered with pleasure, others - with sadness or even bitterness. Each of the accomplished activities provided experience perceived as learning in the work place.

"No one asks me if I can do it or I am able to do it, I just get a task and I have to do it. Then I have to ask a lot of questions, to make many plans and mistakes. Here is the photo of my first big event in another university, where started work a few years ago. There were a lot of mistakes in the organisation process, a lot of emotion, but now, when organising other events I know precisely which parts are the most slippery, what needs the most attention (P3)" (see Figure 4). 


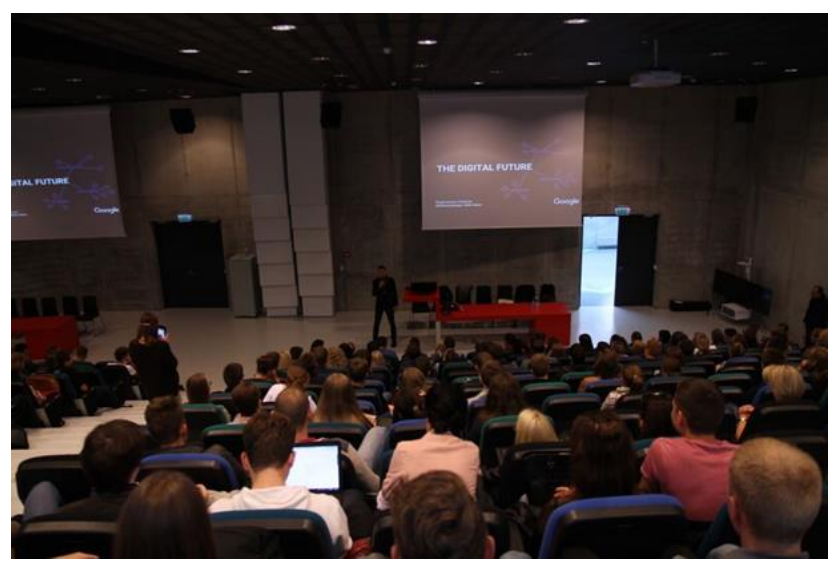

Figure 4: A moment in the conference

Continuous constant feedback as a learning motive was recorded in many interviews. Research participants emphasise the need of qualitative feedback.

"It is really bad when I make the same mistakes again and again. They appear when the in time given for their analysis is insufficient or because of the failure to understand that my action which seems to be appropriate would not be good in this particular situation. (P5)".

Subcategory: Hot events. The work of the university administrator is comprised of many activities, one of which is the most painful in terms of time and emotion. These are different situations that are supposed not to be publicised - complaints, problems, dissatisfaction, situations where people feel undervalued, insulted or hurt. These are moments when it is necessary to make a decision that might not be acceptable to all, when one has to assume responsibility.

"I don't know how to make a photo of problem solving. These are some events where one side necessarily unhappy and hurt. In such situations an administrator has to absorb everything, to clarify the situation, make a decision and assume responsibility. They are emotionally exhaustive and violate self-worth. These are the situations where it is hard to assemble oneself again and work further as usual. But you still can learn from them. After that you become more careful, more reserved, but at the same time you feel vulnerable (P2)" 
Learning in "hot events" is recorded when the problem is solved or analysed.

"If the problem is left unresolved, it does not facilitate learning. Learning only happens when it is analysed, when you notice that in another similar situation you are not repeating the same mistakes. Unfortunately, it happens that there is no time left for the analysis of the problem. (P1)".

The research participants agree that different conflict situations are followed by either the appearance of new documents (the absence of which determined the conflict) or a promise "not to do it any more" which cannot be called learning if the situation is repeating.

"After the conflict at work, I either promise to myself that I will learn from this situation, and I will talk less or will not show the initiative if no one asks. A conflict may also create additional work, for example, creation of some rules. Some document is not the learning space - the absence of such document or ignoring $\mathrm{I}$, as well as everything that follows make up the learning space. (P3)"

\section{The 3rd category. People}

Subcategory: Peer assistance. Considering the specificity of a higher education institution this learning space is the most likely as a category.

"I am leaning from my colleagues, they are older and more experienced and they willingly share their knowledge (P7).

Colleagues were photographed by all the research participants. Relationship with the colleagues as a form of learning most often emerged when other photographs were discussed.

"My Dean is my teacher, my mobile learning space at work. Daily conversations, search for solutions and event analysis are like a flooded river. I would say that it is my main learning stimulus and engine at work. (P4)".

Common activities were distinguished by the research participants as a team reinforcement tool and not so much as a learning space. 
"A team is mostly reinforced by common work. Here is the picture where everyone is in a good mood before work in the garden. There are not many of us. Being there I had a feeling of community which is very important while working with an international team. I presented this photo because work offers opportunities to see cultural differences that you would not learn about from books or articles. (P3)"

Subcategory: The initiatives of social partners. Research participants emphasised people who are not university employees - these are future students and their families, present employers, partners of student practice organisation, sponsors, managers of different projects, competitors.

"I am learning by observation, especially it concerns my greatest competitors, even when I am making decisions I think what they would do. As I am also responsible for marketing, I always observe what and how they do, what means they use, how they communicate. I have a box where I keep the collected adverts, brochures and other things" (P3)

A fairly close relationship between university administrators and social partners and their significant input in the ongoing processes especially in the strategy creation and positioning of the higher education institution were also disclosed. It turned out that social partners eagerly involve into different activities happening in the higher school.

"I remember one meeting when we were planning a future event. We just came without any idea. During the meeting, one social partner directly remarked that it is not good, because in order to achieve quality advance preparation is necessary and there is no point in spending the time if the idea is not yet generated and there is nothing to discuss. Those meetings were true lessons to me. (P6)"

Subcategory: The alumni input. The research showed that university administrators value the input of former students in the development of university activities. Alumni actively participate in the development of study programmes and the university promotion. They are officially included in study committees and it allows the improvement of university activities on the basis of specific suggestion and practice. Learning is identified in the work relationship and conversations

"The meeting of the study committee, when our former student who is an attractive employer now is present, is learning in the workplace for me. He 
relates all things with the labour market and encourages us to think to what extent these things are important and useful (P1)".

\section{The discussion}

The learning of university administrators in the work place in pursuance of higher education quality is inevitable and kind of self-understandable. The accomplished research allows the conclusion that different activities performed at work are still not directly associated with learning. For example, one research participant identified only the formal kind of learning (courses, seminars) stating that all situations are learned not in specific spaces, but from life experience that is applied at work for the accomplishment of the given tasks. In the opinion of this participant only formal learning (seminars) is to be considered learning in the work place, but seminars are too few as it is expected that the academic staff of a university are high qualification workers who have to cope with all tasks on their own.

The analysis of the research results showed that the learning spaces of university administrators, on the one hand, are recognisable due to the study performance function characteristic of these learning institutions. On the other hand, they are highly personalised and determined by the employee experience and functions. It was observed that often these spaces are not perceived and realised. Daily activities, habits and functions were defined by university employees as learning in the workplace only after they were asked to think about that. In the opinion of the research author, it is determined by not giving time for reflection about personal activity when daily routine often influenced by the university activity cycles overshadows the analysis of individual activity.

The opposite results were presented by Bakutytė, Ušečkienè (2016), who maintained that learning in the work place of primary class teachers is identified and is determined by external conditions and employee disposition. Primary class teachers' learning in the work place is defined by the following dimensions: receiving, accumulation and dissemination of information, analysis and development of the teaching activity and competence development.

In the process of systematising and describing the learning spaces of university administrators, categories of dynamics and statics are distinguished. The process (routine, facts, "hot events") and people (peer assistance, social partners' initiative, alumni input) categories could be considered dynamic while the category of the work place (individuality, emotional highlight) is static. Not only daily, but also projected learning was observed related with the strategy creation when employees are planning future activities and spheres of self-development. 
University administrators are mostly encouraged to learn in the work place by expectations when having been delegated some functions a maximum good result is anticipated. Satisfaction of expectations is the most prominent factor deciding the learning of university administrators. The importance of microclimate comprised of permanent feedback and development of interpersonal relationship has also been given attention. These results confirm the statement presented by Tought. (1978) saying that adult learning is a natural process. Adults participate in a variety of learning activities usually planned by them. According to the author, learning is stimulated by the application of knowledge, abilities and skills in life and it is their practical value.

The analysis of the emotional factor showed that trusting and encouraging the employee could work as a factor stimulating learning in the work place and the employee's responsibility for the accomplished activities.

\section{Conclusions}

Learning in the work place of university administrators is perceived only to some extent. Often learning is identified as a component of activity to accomplish certain tasks and not as an indispensable act in order to perform the activity.

Concord of factors significant for career, aspiration to satisfy the expectations, self-realisation motives and suitable microclimate encourages the university administrators' learning in the work place. Trust in the employee emerges as the most important factor ensuring the process of learning in the work place.

The following spaces of university administrators' learning in the work place were identified:

- A physical work place distinguished by the created individuality and emotional highlights,

- routine, historical and "hot events" processes,

- peer assistance, social partners' initiative and alumni input. 


\section{References}

Argyris, C. (1992). On Organizational Learning. Cambridge: Mass Blackwell Publishers.

Awad, E., Ghaziri, H. (2004). Knowledge management. India: Sheel Print N Pack.

Bakutytė, L., Ušečkienè, L. (2016). Pradinių klasių mokytojų mokymosi darbovietėje dimensijų raiškos suvokimas Pedagogika 121(1), 41- 52.

Barnett, R. (2000). Realizing the University in a Age of Super complexity. Buckingham: SRHE.

Cardoso, S. T., Carvalho, T., Santiago, R. (2011). From students to consumers: reflections on the marketization of Portuguese higher education. European Journal of Education, 46 (2), 271- 284 Retrieved from http://onlinelibrary.wiley.com/enhanced/doi/10.1111/j.1465-3435.2010.01447.x.

Edwards, E. (2011). Tracing photography p.p 159- 190 in Banks M., Ruby J. (Ed) Made to Be Seen: Perspectives on the History of Visual Anthropology Retrieved from https://books.google.lt/books?hl=lt\&lr=\&id=MyT9BNwrHU4C\&oi=fnd\&pg=P A159\&ots=VfYpS6dq8N\&sig=K9dv3psZhKL4F9ziOzoAwaSneM4\&redir_esc $=\mathrm{y} \# \mathrm{v}=$ onepage $\& \mathrm{q} \& \mathrm{f}=$ false.

Jokubaitis, A. (2013). Universitetas, kaip gamykla. Retrieved from http://www.postscriptum.lt/nr11-universitetas/universitetas-kaip-gamykla.

Jucevičienè, P. (2007). Besimokantis miestas. Monografija. Kaunas: KTU press.

Jucevičienè, P., Mozuriūnienè, V. (2009). Organizacijos žinojimo santykis su organizacijos žiniomis: pažinimo ir formalizavimo ribos Ekonomika ir vadyba 24 (2), 1129-1138.

Jucevičienè, P., Edintaitė, G. (2012). Organizational learning of teachers in higher education: challenges and opportunities of knowledge management. Proceedings of the 13th European Conference on Knowledge Management Cartagena: Academic Publishing International, 557-566.

Kilduff, M., Mehra, A. (1997). Postmodernism and Organizational Research. Academy of Management Review. 22, 453- 481.

Kolb, B. (2012). Unveiling Spaces with the Participatory Photo Interview in Silva, C. Nunes (Ed). Online Research Methods in Urban and Planning Studies: Design and Outcomes. IGI- Global, 120- 137.

Larson, H. J. (1988). Photography that listens, Visual Anthropology, 1: 415- 432.

Mayring, P. (2000). Qualitative content analysis. Forum: Qualitative Social Research, 12 Art. 20 Retrieved from http://www.nbnresolving.de/urn:nbn:de:0114-fqs0002204 
Misiūnaitè- Bačiauskienė, E., Jucevičienė, P. (2014). Universiteto katedros studijų veiklos žiniu valdymo procesas: teorinis požiūris Pedagogika 2014, 113 (1) 1127.

Nonaka, I., Takeuchi, H. (1995). The knowledge- creating company. Oxford: University press

Polanyi, M. (1958) Personal knowledge. Towards a post- critical philosophy. Chicago: The University of Chicago Press.

Salamavičius, A. (2010). Universiteto idejja ir akademinė industrija. Vilnius: LEU press

Tought, A. (1978) Major Learning Efforts: Recent Research and Future Directions. Adult Education, 28 250- 263.

Vettori, O, Lueger M., Knassmüller, M., (2007). Dealing with Ambivalences. Strategic Options for Nurturing a Quality Culture in Teaching and Learning p.p.21-27 In European University Association: Embedding Quality Culture in Higher Education. A Selection of Paper from the 1st European Forum for Quality Assurance (Brussels: European University Association)

Webster, F. (2009). The Postmodern University, Research and Media Studies Retrieved from http://cjms.fims.uwo.ca/issues/07-01/Frank\%20Webster.pdf

Zhang, Y., Wildemuth, B. (2009). Qualitative analysis of content. In. B. Wildemuth (ed.) Applications of social science research methods to questions in library and information science. Englewood, CO: Libraries Unlimited. 